\title{
Surfactant Replacement Therapy from 1986 to 2006: A 20-Year Success Story
}

On 26th April 1986, twenty-six scientists met in Amsterdam to discuss a new achievement in the care of newborn infants. Bengt Robertson and Tore Curstedt had developed a porcine surfactant for clinical use to treat respiratory distress syndrome (RDS) in the preterm neonate. The first randomized controlled trial had been running for over 12 months and the group met to discuss its progress and plan further studies. The product was not registered at this time and no commercial interests stood behind its early development. The small gathering in Amsterdam that later turned out to be the 1st International Workshop on Surfactant Replacement was driven by a genuine interest to improve health and survival of preterm infants who suffered high mortality rates after developing severe RDS. In retrospect, the meeting in Amsterdam was one of the most important in achieving these goals. Today, 20 years later, almost 600,000 newborn infants have been treated with this surfactant with the generic name poractant alfa. In the original study, mortality in the control group of infants who had birth weights between 700 and 2,000 g, severe RDS and oxygen requirements $\geq 60 \%$ was about $50 \%$. One intratracheal dose of poractant alfa reduced mortality to about $30 \%$. Later trials showed that with multiple doses and more experience the mortality was reduced further to about $10 \%$ which constituted a revolution in the care of these ill preterm babies. Tens of thousands of lives have been saved by this and similar surfactants. Today 20 years lat- er, more than 5,000 infants have been randomized into various studies of poractant alfa. More than 1,500 articles have been published and the annual international workshops have become more and more popular. The Amsterdam meeting involved clinical as well as basic science researchers which was fortunate indeed.

The International Workshops on Surfactant Replacement still attract the same group of enthusiastic clinical and basic science researchers. Since 1986, the group has grown and it has now become global forming a powerful and efficient research network to conduct ongoing trials. The group has also been able to support work in Tibet through the Chiesi Farmaceutici foundation in Parma. In the last 2 years, the foundation has contributed to tree planting and the building of a new school in the Nepu village. A medical dispensary with a few beds for more severely ill patients also will be built and will serve not only the Nepu village but also the surrounding villages.

In 2006, 20 years after the first workshop, we are meeting in Oslo for the second time. Surfactant therapy was introduced into Norway when the first infant was treated with Curosurf in the National Hospital in spring 1987. The introduction of this therapy was initially met with substantial resistance but today it is considered so evidently beneficial that it is accepted by all and a younger generation of doctors and nurses cannot remember the days when half of the babies with RDS died.

\begin{tabular}{ll}
\hline KARGER & ○ 2006 S. Karger AG, Basel \\
0006-3126/06/0894-0282\$23.50/0 \\
$\begin{array}{l}\text { Fax +4161306 1234 } \\
\begin{array}{l}\text { E-Mail karger@karger.ch } \\
\text { www.karger.com }\end{array}\end{array}$ & $\begin{array}{l}\text { Accessible online at: } \\
\text { www.karger.com/bon }\end{array}$
\end{tabular}


In this year's meeting the scientific level is as high as ever before. This is demonstrated by the eight excellent invited lectures together with the free papers comprising both oral and poster presentations.

The 9th Nils W. Svenningsen Memorial Lecture was given this year by Petra Hüppi from Geneva. She is a long-standing member of the group and her studies on brain MRI are highly rated and respected. Alan Jobe from Cincinnati gave an overview on 'Why surfactant works'. Linda van Marter from Boston provided the latest summary on risk factors and preventive strategies for bronchopulmonary dysplasia (BPD). Peter Burri from Berne presented new information about lung development, especially in the postnatal period. Henry Halliday from Belfast discussed the most recent trials with surfactant and Tore Curstedt from Stockholm continued to lead us into the exciting development of new synthetic surfactants.
Ron Clyman from San Francisco provided an overview of patent ductus arteriosus and the pathophysiological basis for current treatment strategies. Istvan Seri from Los Angeles gave a review of the pulmonary and systemic effects of inotrope drugs.

This issue of Biology of Neonate, with the articles and abstracts from the 21 st International Workshop on Surfactant Replacement, published 20 years after the first meeting in Amsterdam reminds us of the considerable impact surfactant has had on newborn and infant health worldwide.

Ola Didrik Saugstad, Oslo Tore Curstedt, Stockholm Henry L. Halliday, Belfast Bengt Robertson, Stockholm Christian P. Speer, Würzburg 